\section{SP0211 DEVELOPMENT OF A STANDARDIZED TRAINING MODEL FOR ULTRASOUND-GUIDED SYNOVIAL BIOPSY'S IN SMALL AND LARGE JOINTS}

Ingrid Möller. University of Barcelona, Instituto Poal de Reumatologia, Barcelona 08022, Spain

Background: Ultrasound-guided needle biopsy of synovium is a minimally invasive tool to complete the study and in the investigation of the therapeutic response in some patients with arthritis. As a consequence, there is a need to have a didactic material and a form of training. This EULAR project: Development of a standardized training model for ultrasound-guided synovial biopsy's in small and large joints, covers these objectives

Objectives:

1. To develop educational material on the procedures for ultrasound-guided minimally-invasive synovial biopsy in small and large joints.

2. To test the consistency, reliability and feasibility of these procedures on cadaveric specimens (Barcelona University, Barcelona, Spain).

3. To validate these procedures by assessing the synovial tissue quality (i.e. number of graded tissue samples per biopsy procedure, amount of RNA extraction) obtained by this biopsy modality in patients (5 patients) from the participating centres. Tissue will be analyzed in a central laboratory (Joint and Bone Laboratory, Fundación Jiménez Díaz, Madrid, Spain).

Methods: Meeting in Barcelona was in January 2019 from the 21 to the 25.

During the meeting, part of the educational material was produced and the exercise to test the consistency, reliability, and feasibility of these procedures on cadaveric specimens (Barcelona University, Barcelona, Spain) was done. Then the material was circulated among the experts.

The validation of these procedures by assessing the synovial tissue quality (i.e. number of graded tissue samples per biopsy procedure, amount of RNA extraction) obtained by this biopsy modality in patients ( 5 patients) from the participating centres and Tissue analysis in a central laboratory (Joint and Bone Laboratory, Fundación Jiménez Díaz, Madrid, Spain) is ongoing

Results: Here is presented the teaching material produced by the members of this EULAR task force in animal model and cadaver as a basis for learning the ultrasound-guided synovial biopsy technique.

Conclusion: The animal model and the cadaver, having the appropriate anatomical and musculoskeletal ultrasound knowledge, are useful for learning ultrasoundguided biopsy. As a complement, you can include the stay with an expert to face the problems of the technique with the real patient. The visualization of the produced video is a useful tool for this learning.

\section{REFERENCES:}

[1] Gerlag D, Tak PP. Synovial biopsy. Best practice \& research. 2005;19:387-400

[2] Vordenbaumen S, Joosten LA, Friemann J, et al. Utility of synovial biopsy. Arthritis research \& therapy. 2009;11:256.

[3] Bresnihan B, Pontifex E, Thurlings RM, et al. Synovial tissue sublining CD68 expression is a biomarker of therapeutic response in rheumatoid arthritis clinical trials: consistency across centers. The Journal of rheumatology. 2009;36:1800-1802.

[4] Kraan MC, van Kuijk AW, Dinant HJ, et al.Alefacept treatment in psoriatic arthritis: reduction of the effector $\mathrm{T}$ cell population in peripheral blood and synovial tissue is associated with improvement of clinical signs of arthritis. Arthritis and rheumatism. 2002:46:2776-2784.

[5] Tak PP. Analyzing synovial tissue samples. What can we learn about early rheumatoid arthritis, the heterogeneity of the disease, and the effects of treatment? J Rheumatol Suppl. 2005;72:25-26.
[6] van de Sande MG, Gerlag DM, Lodde BM, et al. Evaluating antirheumatic treatments using synovial biopsy: a recommendation for standardisation to be used in clinical trials. Annals of the rheumatic diseases. 2011;70:423 427.

[7] Vos K, Thurlings RM, Wijbrandts CA, et al. Early effects of rituximab on the synovial cell infiltrate in patients with rheumatoid arthritis. Arthritis and rheumatism. 2007;56:772-778.

[8] Saaibi DL, Schumacher HR, Jr. Percutaneous needle biopsy and synovial histology. Bailliere's clinical rheumatology. 1996;10:535-554.

[9] Koski JM, Helle M. Ultrasound guided synovial biopsy using portal and forceps. Annals of the rheumatic diseases. 2005;64:926-929.

[10] van Vugt RM, van Dalen A, Bijlsma JW. Ultrasound guided synovial biopsy of the wrist. Scand J Rheumatol. 1997;26:212-214.

[11] Kelly S, Humby F, Filer A, et al. Ultrasound-guided synovial biopsy: a safe, well-tolerated and reliable technique for obtaining high-quality synovial tissue from both large and small joints in early arthritis patients. Annals of the rheumatic diseases. 2013.

Disclosure of Interests: None declared

DOI: 10.1136/annrheumdis-2019-eular.8539

SATURDAY, 15 JUNE 2019

$13: 45: 00-14: 45: 00$

HPR Highlight session

\section{SP0212 HIGHLIGHTS FROM THE SCIENTIFIC PROGRAMME}

Daniel Aletaha. Medical University of Vienna, Department of Medicine III, Division of Rheumatology, Austria

In this presentation we will review the most interesting findings from the scientific programme of this year's EULAR meeting for for Health Care Professionals. Disclosure of Interests: Daniel Aletaha Grant/research support from: AbbVie Bristol-Myers Squibb, and MSD, Consultant for: AbbVie, Bristol-Myers Squibb, Eli Lilly, Janssen, Medac, Merck, MSD, Pfizer Inc, Roche, and UCB, Speakers bureau: AbbVie, Bristol-Myers Squibb, Eli Lilly, Janssen, Medac, Merck, MSD,

Pfizer Inc, Roche, and UCB

DOI: 10.1136/annrheumdis-2019-eular.8414

SATURDAY, 15 JUNE 2019

13:45:00 - 14:45:00

\section{PARE Highlight session}

\section{SP0213 HIGHLIGHTS FROM THE SCIENTIFIC PROGRAMME}

Alexandre Sepriano. Leiden University Medical Center, Rheumatology, Leiden, Netherlands

This talk will cover highlights from the Congress Scientific Programme, encom passing a wide range of topics in the field of rheumatology

Disclosure of Interests: None declared

DOI: 10.1136/annrheumdis-2019-eular.85 